\title{
Pelanggaran Hak Cipta Melalui Internet (Studi Kasus: Itar-Tass Russian Agency Melawan Russian Kurier Agency)
}

\author{
Rehulina Tarigan
}

Dosen Bagian Hukum Internasional Fakultas Hukum Unila

\begin{abstract}
Abstrak
Kasus Itar-Tass Russian Agency melawan Russian Kurier Agency yang berkaitan dengan hak cipta, perkara ini dimulai ketika warga negara Rusia menggandakan dan menyebarluaskan karya sastra warga negara Amerika Serikat, penggandaan ini dilakukan di Inggris dan disebarluaskan di Cina. Dalam Perkara ini terdapat 4 negara, yaitu Rusia (negara pelaku pelanggaran), Amerika Serikat (orang yang hak ciptanya dilanggar), Inggris (tempat terjadinya pelanggaran) serta Cina (tempat penyebarluasan). Apabila warga negara Amerika hendak menuntut ganti rugi kepada warga negara Rusia yang telah melakukan pelanggaran terhadap hak ciptanya, maka kemanakah tuntutan tersebut harus diajukan, Hukum apakah yang akan digunakan oleh hakim dalam menyelesaikan sengketa ini, merupakan permasalahan yang hendak ditemukan jawabnya. Berdasarkan kajian teoretis ditemukan jawaban bahwa peradilan yang berhak menangani perkara ini adalah peradilan Amerika Serikat. Sedangkan untuk menentukan hukum yang digunakan menyelesaikan perkara tersebut, hakim menggunakan kualifikasi bertahap, pada tahap pertama hakim Lex Fori mengunakan hukum atas dasar; karya cipta dalam sengketa adalah hasil karya dari warga Negara Rusia, Karya cipta ini pertama kali dipublikasikan di Rusia dan County of Origin-nya adalah Rusia, setelah hakim Lex Fori memutuskan bahwa hukum Rusia yang di gunakan makan hakim melakukan kulifikasi tahap kedua, pada tahap ini hakim melihat bahwa berdasarkan ketentuan perundang-undangan Rusia perkara ini masuk dalam klasifikasi berdasarkan kepemilikan, dan hukum Rusia menunjuk hukum yang belaku bagi kepemilikan adalah hukum pemilik.artinya, hukum Amerikalah yang berwenang untuk itu.
\end{abstract}

Kata kunci : Pelanggaran Hak Cipta, internet dan perdata internasional.

\section{Pendahuluan}

Teknologi informasi dan komunikasi mengubah perilaku masyarakat dan peradaban global. Di samping itu, perkembangannya menjadikan dunia menjadi tanpa batas (borderless) dan perubahan sosial yang secara signifikan berlangsung demikian cepat. ${ }^{1}$

\footnotetext{
${ }^{1}$ Ahmad M. Ramli, Cyber Law dan HAKI, Dalam Sistem Hukum Indonesia, Refika Aditama, Bandung, 2004, hlm. 1.
}

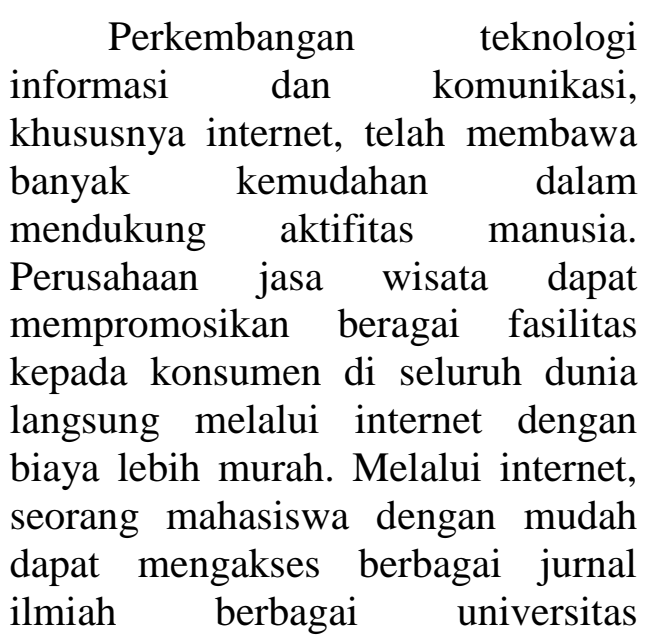


terkemuka seluruh dunia, di samping memberikan manfaat, tingginya penggunaan teknologi informasi memberikan akibat berupa ancaman terhadap eksistensi karya cipta dan invensi yang ditemukan oleh para penemu Hak Kekayaan Intelektual. Karya-karya intelektual berupa program komputer dan objek-objek hak cipta yang ada di media internet dengan sangat mudah dilanggar, dimodifikasi dan digandakan. ${ }^{2}$

Berbagai bentuk pelanggaran hak cipta dalam internet telah berkembang demikian cepat. Pelanggaran-pelanggaran hak cipta tersebut dapat berupa mengkopi hasil karya cipta dari internet, baik berupa tulisan, musik ataupun film, dan menyebarluaskannya tanpa izin, menggunakan nama-nama dari orang terkenal ataupun perusahaanperusahaan besar sebagai nama domain tanpa izin, dan berbagai bentuk pelanggaran lainnya.

Negara-negara telah memiliki berbagai perangkat hukum guna melindungi hak cipta warga negaranya. Masyarakat internasional bahkan telah menghasilkan suatu Konvensi Internasional berkaitan dengan perlindungan hak cipta.

Namun demikian upaya penegakan hukum berkaitan dengan pelanggaran hak cipta yang dilakukan melalui internet cukup sulit, karena kerapkali pelanggaran-pelanggaran tersebut melibatkan unsur-unsur asing.

Sebagai ilustrasi, seorang warganegara Rusia menggandakan dan menyebarluaskan karya sastra seorang warganegara Amerika Serikat. Penggandaan tersebut dilakukan di Inggris dan hasil dari penggandaan tersebut di

\footnotetext{
${ }^{2}$ Ibid, hlm. 6.

${ }^{3}$ Berne Convention For The Protection of Literary and Artistic Works.
}

sebarluaskan di Cina. Dalam ilustrasi tersebut ada 4 unsur asing yang terlibat, yakni Rusia (warganegara pelaku pelanggaran), Amerika Serikat (orang yang hak ciptanya dilanggar), Inggris (tempat terjadinya pelanggaran) serta Cina (tempat disebarluaskannya karya sastra yang telah digandakan). Apabila kemudian warganegara Amerika hendak menuntut ganti rugi kepada warga negara Rusia yang telah melakukan pelanggaran terhadap hak ciptanya, maka kemanakah tuntutan tersebut harus diajukan, Hukum apakah yang akan digunakan oleh hakim dalam menyelesaikan sengketa tersebut. Untuk menjawab pertanyaan-pertanyaan demikian, maka diperlukan teori-teori maupun ketentuan-ketentuan Hukum Perdata Internasional. Oleh karena itu masalah pelanggaran hak cipta melalui internet memiliki kaitan yang erat dengan Hukum Perdata Internasional.

$$
\text { Konvensi Berne dan }
$$

Kesepakatan TRIPs (Trade Related Aspects of intellectual Property Right) mencoba untuk mengharmonisasikan hukum hak cipta di seluruh dunia. Namun demikian, konvensi ini belum menciptakan suatu ketentuan hak cipta yang seragam dengan mana seluruh negara di dunia memiliki hukum hak cipta yang sama. ${ }^{4}$

Salah satu contoh kasus adalah sengketa antara Itar-Tass Russian Agency dengan Russian Kurrier, inc. Sengketa ini berkaitan

\footnotetext{
${ }^{4} \mathrm{Yu}$, Peter K, Conflict of Laws Issues in International Copyright cases, http://www.gigalaw.com/articles/2001/18/12 /205 lihat http://en.wikipedia.org/wiki/ItarTass_Russian_News_Agency_v._Russian_K urier,_Inc.\#Case history di download pada 08.30 Tanggal 13 Mei 2013
} 
dengan masalah sengketa kepemilikan dan pelanggaran hak cipta. Pengadilan manakah yang berwenang mengadili sengketa antara Itar-Tass Russian Agency dengan Russian Kurrier, inc dan Hukum manakah yang harus digunakan oleh hakim dalam menyelesaikan sengketa antara ItarTass Russian Agency dengan Russian Kurrier, inc?

\section{II.Pembahasan}

kasus ini merupakan kasus antara Itar-Trass Russian New Agency (Berkedudukan di Rusia) versus Russian Kurrier.Inc (Berkedudukan di New York, Amerika Serikat), berikut ini di jabarkan fakta-fakta yang terkait dengan kasus ini;

\section{A. Kasus Posisi dan dasar Gugatan}

Itar-tass Russian News Agency (penggugat) merupakan sebuah korporasi yang bergerak dalam bidang usaha mempublikasikan, harian atau mingguan, surat kabar yang sebagian besar berbahasa Rusia di Rusia atau Israel. Itar-tass Russian terdiri dari berbagai perusahaan berita serta para wartawan yang bekerja pada perusahaan berita tersebut.

Russian Kurrier (Tergugat) merupakan perusahaan majalah mingguan berbahasa Rusia yang berkedudukan dan mendistribusikan terbitannya di wilayah New York, Amerika Serikat.

Russian Kurrier telah mengkopi sekitar sekitar 500 artikel yang sebelumnya (pertama kali) telah dipublikasikan pada surat kabar dari para penggugat dan telah didistribusikan oleh Itar-Tass.
Russia Kurrier juga telah mengkopi artikel-artikel yang berisi headline, gambar-gambar, by-lines, grafik, sebagai tambahan pada teks, yang kemudian di masukkan ke dalam halaman lay-out, direproduksi serta di print pada halaman-halaman terbitan Russian Kurrier.

Tindakan Russian Kurrier yang mengcopy artikel, gambar, headline maupun grafik-grafik dari karya para penggugat dilakukan tanpa memperoleh izin terlebih dulu dari para penggugat.

\section{B. Tinjauan Umum Hukum Perdata Internasional}

Untuk mendapat gambaran yang jelas mengenai pengertian serta ruang lingkup Hukum Perdata Interbasional (HPI) maka perlu diperhatikan definisi yang diberikan oleh beberapa ahli berikut :

Sudargo Gautama mengartikan HPI sebagai Berikut :

Keseluruhan peraturan dan keputusan-keputusan yang menunjuk-kan stelsel-stelsel hukum manakah yang berlaku atau apakah yang merupakan hukum, jika hubungan-hubungan dan peristiwa antara warga (warga) negara pada satu waktu tertentu memperlihatkan titik-titik pertalian dengan stelselstelsel dan kaidah-kaidah hukum dari dua atau lebih negara, yang berbeda dalam lingkunganlingkungan kuasa tempat, (pribadi)dan soal-soal.

Sunaryati Hartono memandang inti dari HPI adalah pergaulan hidup masyarakat internasional. Oleh karena itu Sunaryati lebih condong

\footnotetext{
5 Sudargo Gautama, Hukum Perdata Internasional Indonesia, Buku Kedelapan, Jilid ketiga (Bagian Dua), Alumni, Bandung, 1998, hlm. 21.
} 
untuk menamakan Hukum Perdata Internasional "Hukum Pergaulan Internasional", sebab bukan sifat perdatanya atau pun sifat internasionalnya yang menentukan kaedah-kaedah HPI, akan tetapi pergaulan internasionallah (jadi hubungan-hubungan internasional), yang menetukan corak kaedahkaedah HPI. ${ }^{6}$

Adapun yang menjadi pokok persoalan dalam HPI, adalah : ${ }^{7}$

1. Hakim atau Badan Peradilan manakah yang berwenang menyelesaikan perkara-perkara Hukum yang mengandung unsur asing.

2. Hukum manakah yang harus diberlakukan untuk mengatur dan/atau menyelesaikan persoalan-persoalan hukum yang mengandung unsur asing.

3. Bilamana/sejauhmanakah suatu pengadilan harus memperhatikan dan mengakui putusan-putusan hukum asing atau mengakui hakhak yang terbit berdasarkan hukum atau putusan pengadilan asing.

\section{Perbuatan Melawan Hukum}

Kaidah-kaidah HPI yang mengatur materi ini tidak sematamata dibataskan kepada perbuatanperbuatan melanggar hukum yang telah dilakukan dengan sengaja, karena kesalahan pihak yang melakukan, baik secara intentional (dengan sengaja) atau hanya karena kelalaian (negligance). Disini termasuk juga tanggung jawab yang

6 C.F.G. Sunaryati hartono, Pokok-Pokok Hukum Perdata Internasional, Binacipta, bandung, 1989.

${ }^{7}$ Bayu Seto, Dasar-Dasar Hukum Perdata Internasional, Citra Aditya Bakti, Bandung, 2001, hlm. 15-16, C.F.G. Sunaryati hartono, op.cit, hlm. 14. disebabkan perbuatan melawan hukum tanpa kesalahan. ${ }^{8}$

Ada beberapa teori berkaitan dengan penentuan hukum yang berlaku dalam memutus sengketa akibat perbuatan melawan hukum, yaitu :

\section{Hukum Tempat Terjadinya Perbuatan Melawan Hukum (Lex Loci Delicti Commissi). \\ Kaidah Lex Loci Delicti}

Commissi atau disingkat dengan Lex Loci Delicti, merupakan kaidah yang tertua dan umum diterima sejak lama tanpa menemukan tantangan sedikitpun. Berdasarkan kaidah ini, hukum yang berlaku untuk perbuatan melanggar hukum ialah hukum dimana perbuatan itu dilakukan (terjadi). Hukum ini menentukan baik mengenai syarat-syaratnya (jadi mengenai pertanyaan apakah telah terjadi suatu perbuatan melanggar hukum), maupun juga sampai sejauh mana akibat-akibat daripadanya.

Namun demikian, kaidah lex loci delicti ini dianggap terlalu kaku sebagai hard fast rule kurang memperlihatkan souplesse yang demikian diperlukan bilamana hendak memenuhi kebutuhankebutuhan hukum yang demikian aneka warnanya dalam realitas kehidupan sehari-hari.

\section{Prinsip Lex fori}

Oleh penulis kenamaan abad ke-19, Wachter dan Savigny telah dipupuk pendirian bahwa dalam perkara-perkara perbuatan melanggar hukum selalu harus digunakan hukum dari forum sang hakim. Hal ini disebabkan karena kaidah-kaidah yang mengatur persoalan perbuatan melanggar hukum dan akibatakibatnya mengenai penggantian

\footnotetext{
${ }^{8}$ Sudargo Gautama, op.cit, hlm. 116.

${ }^{9}$ Sudargo Gautama, op.cit., hlm. 119-121.
} 
kerugian adalah bersifat demikian memaksa, karena segi-segi ethisnya, hingga hakim dari setiap negara tidak akan menyimpang darinya.

\section{Kombinasi Pemakaian Lex Loci dan Lex Fori \\ 1) Prinsip Persamaan dari HPI Inggris. \\ Dalam HPI Inggris yang} berkaitan dengan perbutan melawan hukum, ada dua unsur penting yang harus dipenuhi guna dikabulkannya tuntutan gati rugi untuk perbuatanperbuatan di luar negeri :

\section{a) Actionability}

Syarat ini berarti bahwa tindakan sengketa dari tergugat apabila dilakukannya di dalam wilayah Inggris akan merupakan suatu perbuatan tort pula yang membawa kewajiban membayar ganti rugi.

\section{b) Justifibiality}

Syarat ini mengaitkan sesuatu kepada lex locus delicti. Perbuatan yang disengketakan harus juga merupakan perbuatan melanggar hukum ditempat dimana ia dilakukan.

Selain itu berlaku pula prinsip similiarity atau similitude. Hal ini berarti bahwa apabila hukum asing dimana perbuatan sengketa terjadi menghapuskan tuntutan maka penghapusan itu berarti pula suatu pembebasan untuk tuntutan dari suatu pihak di negara Inggris.

\section{2) Vorbehaltklausel dari HPI Jerman.}

Pada asasnya dipakai lex loci delicti untuk perbuatan melawan hukum menurut HPI Jerman. Tapi pasal 12 EGBGB jerman memberikan pembatasan yang penting bagi orang-orang Jerman. Mereka tidak dapat dituntut di Jerman untuk perbuatan-perbuatan melanggar hukum yang dilakukan diluar negeri untuk jumlah yang lebih besar dari apa yang mereka wajib menurut ketentuan-ketentuan hukum Jerman.

\section{Pelembutan kaidah Klasik}

1) The Proper Law of a Tort Proper law of a tort pada dasarnya adalah sama dengan the proper law of a contract. Alam menetukan hukum yang akan digunakan dalam memutus sengketa adalah dengan memperhatikan apa yang dinamakan center of gravity atau grouping of contracts atau memperhatikan negara manakah yang memiliki The Most Significant contacts dengan apa yang menjadi sengketa.

2) Sozialle Umwelt

Menurut teori ini, perbuatan melawan hukum harus ditentukan menurut sistem hukum hukum dalam suasana sosial manakah perbuatan itu dengan akibatnya telah berlangsung. Pada umumnya maka sistem hukum ini adalah hukum dari tempat terjadinya perbuatan itu. Tetapi ini tidak selalu harus demikian adanya.

Hal penting lain berkaitan dengan perbuatan melawan hukum adalah penetuan tempat (locus) di mana terjadinya perbuatan melawan hukum. Ada beberapa teori berkenaan dengan perbuatan melawan hukum, yaitu :

a. Teori Tempat Terjadinya Kerugian;

Menurut teori ini, titik berat diletakkan atas tempat dimana kerugian timbul.

b. Teori Tempat Dimana dilakukannya Perbuatan;

Di negara Eropa Kontinental, sistem yang paling banyak dianut ialah bahwa titik berat harus 
dilakukan atas tempat dimana si pelanggar berbuat.

c. Teori Kombinasi Dengan Kebebasan Memilih;

Teori ini merupakan kombinasi antara teori tempat terjadinya kerugian dengan teori tempat dimana dilakukannya perbuatan. Sang korban bebas memilih hukum manakah ia lebih sukai: tempat dimana perbuatan dilakukan atau tempat akibat nampak. Ke dua tempat ini samasama merupakan locus.

\section{Analisis Kasus}

Dalam menyelesaikan suatu sengketa HPI, terdapat beberapa pola berfikir yuridik yang perlu diikuti, yaitu :

1. Hakim menghadapi persoalan hukum dalam wujud sekumpulan fakta hukum yang mengandung unsur-unsur asing (foreign elements) dan harus menentukan apakah perkara merupakan persoalan HPI. ${ }^{10}$

Pada tahap ini hakim menyadari adanya fakta-fakta di dalam perkara yang menunjukkan adanya keterkaitan antara perkara ini dengan tempat-tempat asing (tempattempat di luar wilayah Negara forum). ${ }^{11} \quad$ Fakta-fakta yang menunjukkan bahwa hakim sedang menghadapi suatu masalah HPI tersebut dinamakan Titik Pertalian Primer atau Titik Taut Pembeda. Titik taut primer dapat berbentuk : kewarganegaraan fihak yang bersangkutan, bendera kapal asing, domisili, tempat tinggal, tempat asal seseorang, atau domisili tempat

${ }^{10}$ Bayu Seto, op.cit, hlm. 9.

${ }^{11}$ Ibid. kedudukan suatu badan hukum. ${ }^{12}$ Dalam sengketa antara Itar-Tass Russian Agency dengan Russian Kurrier, inc, yang menjadi titik taut primer atau titik taut penentu adalah tempat kedudukan dari pihak penggugat, yaitu Russian Kurrier, inc, yang berkedudukan di Rusia.

2. Hakim harus menentukan ada/tidaknya kewenangan yuridiksional forum untuk mengadili perkara yang bersangkutan. ${ }^{13}$

Dalam setiap kasus HPI, sebelum sampai pada masalah hukum apakah yang akan digunakan, terlebih dulu harus ditentukan forum manakah yang berwenang memutus perkara tersebut.

Dalam hukum Acara HPI, terdapat 3 forum yang berwenang memutus suatu sengketa HPI, yaitu :

a. Forum Rei.

Bahwa forum (pengadilan) yang berwenang memutuskan suatu sengketa adalah forum di mana tergugat bertempat tinggal. Dalam hal tergugat lebih dari satu, dimana para tergugat bertempat tinggal di wilayah yang berlainan, maka gugatan dapat diajukan pada pegadilan dari tempat tinggal salah satu tergugat.

\section{b. Forum Rei Sitae.}

Bahwa forum (pengadilan) yang berwenang memutuskan suatu sengketa adalah forum di mana letak benda. Benda dimaksud di sini adalah benda tak bergerak.

\section{c. Forum Actus.}

\footnotetext{
${ }^{12}$ Sudargo Gautama, Pengantar Hukum Perdata Internasional, Putra Abardin, Jakarta, 1999, hlm. 25-34. Sunaryati hartono, op.cit., hlm. 87-88.

${ }^{13}$ Bayu seto, op.cit,. hlm. 10.
} 
Dalam hal tergugat tidak mempunyai tempat tinggal yang diketahui maka gugatan dapat diajukan ke pengadilan di mana penggugat bertempat tinggal.

Pada sengketa antara Itar-Tass Russian Agency melawan Russia Kurrier, forum yang berwenang untuk memutus sengketa adalah pengadilan Amerika Serikat. Hal ini karena Russian Kurrier selaku tergugat, berkedudukan di New York, Amerika Serikat. Dipilihnya pengadilan New York sebagai tempat untuk menyelesaikan sengketa adalah didasarkan pada principle basis of presence serta prinsip forum of convenience. Forum of convenience berarti bahwa forum yang dipilih dalam menyelesaikan sengketa adalah forum yang paling menguntungkan tergugat, di mana tergugat dapat melakukan pembelaan, dalam hal ini adalah forum di mana tergugat bertempat tinggal.

3. Mencari dan menemukan kaidah HPI yang tepat melalui tindakan kualifikasi.

Setelah hakim sampai pada simpulan bahwa suatu sengketa merupakan suatu masalah HPI dan telah mengetahui forum yang berwenang memutus sengketa, hakim selanjutnya harus menentukan hukum apakah yang akan digunakan dalam memutus sengketa tersebut. Namun sebelum itu, hakim terlebih dahulu harus melakukan kualifikasi. Kualifikasi sebenarnya adalah melakukan "translation" atau "penyalinan" daripada fakta-fakta sehari-hari dalam istilah-istilah hukum. Fakta-fakta ini dimasukkan dalam kotak-kotak hukum, kelaskelas, ruang-ruang atau kamar-kamar atau bagian-bagian hukum yang sudah tersedia. ${ }^{14}$ Berdasarkan kualifikasi tersebut hakim dapat memasukkan fakta-fakta yang ada ke dalam golongan hukum benda, hukum orang, perjanjian atau perbuatan melawan hukum.

Pada tahap pertama, hakim melakukan kualifikasi Primer atau "Qualifikation ersten Grades", adalah kwalifikasi yang diperlukan untuk dapat menentukan hukum yang harus dipergunakan. Untuk dapat menentukan hukum asing manakah yang dipergunakan harus dilakukan kwalifikasi menurut kaidah-kaidah HPI dari lex fori. Kaidah-kaidah HPI dari lex fori ini harus dikwalifikasikan menurut hukum materil sang Hakim. ${ }^{15}$

Kualifikasi dilakukan secara bertahap, yaitu :

\section{Kualifikasi tahap Pertama/ kualifikasi Primer/Qualifikation ersten Grades/Primary classifikation/Qualificatie in de erste graad.}

Kualifikasi ini dilakukan dalam rangka menetapkan lex cause. Kualifikasi pada tahap ini harus dilaksanakan berdasarkan lex fori. ${ }^{16}$ Kaidah-kaidah HPI dari lex fori ini harus dikwalifisir menurut hukum materiil dari hakim. ${ }^{17}$

Berdasarkan fakta-fakta yang ada, para tergugat telah mengkopi dan mempublikasikan kembali karya cipta dari para penggugat tanpa seizin penggugat selaku pemilik hak cipta. Menurut ketentuan pasal 106 US Copyright Act 1976, pemilik karya cipta memiliki hak eksklusif untuk mereproduksi karya cipta baik dengan mengkopi maupun dengan media rekaman. Pemilik hak cipta

\footnotetext{
${ }^{14}$ Sudargo Gautama, op.cit, hlm. 119.

${ }^{15}$ Ibid, hlm. 131.

${ }^{16}$ Bayu Seto, op.cit., hlm. 63.

${ }^{17}$ Sudargo Gautama, op.cit., hlm. 131.
} 
juga memiliki hak eksklusif atas publisitas karya-karya tersebut. Sesuai dengan ketentuan pasal 501 US Copyright Act 1976, maka setiap orang yang melakukan pelanggaran terhadap hak eksklusif dari pemilik hak cipta sebagaimana ketentuan pasal 106, berarti telah melakukan suatu pelanggaran terhadap hak cipta. Dengan demikian perbuatan tergugat dapat digolongkan sebagai perbuatan melawan hukum.

Menurut US Copyright Act 1976, hanya pemiliki dari hak eksklusif atas hak cipta yang berhak mengajukan gugatan. Dengan demikian, kepemilikan (ownership) merupakan dasar bagi gugatan atas suatu perbuatan melawan hukum terhadap hak cipta. Oleh karena itu harus ditentukan terlebih dahulu siapakah yang merupakan pemilik (ownership) dari karya cipta yang menjadi pokok sengketa.

\begin{tabular}{llr}
\multicolumn{2}{c}{ Penentuan } & \multicolumn{2}{r}{ kepemilikan } \\
(ownership) & adalah & untuk \\
menentukan & apakah & Itar-Tass \\
Russian & Agency & memiliki \\
kepentingan & yang cukup, & sebagai
\end{tabular} dasar untuk menggugat tindakan tergugat yang mengkopi artikelartikel individu, yang dipublikasikan pada surat kabarnya, ataukah gugatan tersebut hanya dapat dituntut oleh reporter yang menulis artikel tersebut secara pribadi. ${ }^{18}$

Dalam teori HPI, masalah kepemilikan (ownership) yang menjadi dasar untuk dapat menentukan siapakah yang berhak mengajukan tuntutan merupakan persoalan pendahuluan, sebagai anggota dari Berne Convention For The Protection of Literary and

18 Newman, Jon O, An Introduction to Intellectual Property, www.law.uconn.edu/homes/swilf/ip/cases/it ar.htm (18/12/2005), hlm. 2.
Artistic Works, Amerika Serikat terikat oleh prinsip Nasional Treatment. Berdasarkan prinsip ini, suatu negara anggota harus melindungi pekerjaan dari autor asing sebagaimana perlindungan yang diberikan kepada autor dalam negeri. ${ }^{19} \quad$ Untuk mendapat perlindungan, pemilik dari suatu karya cipta harus jelas. Namun demikian, Konvensi Berne ternyata tidak mengatur mengenai masalah hukum apakah yang akan digunakan dalam menentukan kepemilikan (ownership) atas suatu kekayaan intelektual, Untuk menentukan kepemilikan (ownership) dari suatu karya cipta, Pengadilan Amerika Serikat melakukan pendekatan melalui penafsiran prinsip National Treatment.

Terdapat dua penafsiran dari Prinsip National Treatment, yaitu: ${ }^{20}$

a. Menurut Nimmer, berdasarkan Prinsip National Treatment hukum yang berlaku adalah hukum dimana pelanggaran terjadi. Hukum yang berlaku mengatur semua elemen dari tindakan pelanggaran, tanpa memandang kewarganegaraan dari penulis, country of origin dari karya cipta serta tempat pertama karya tersebut dipublikasikan. Penafsiran yang dilakukan oleh Prof Nimmer ternyata tidak meyakinkan, karena penafsiran tersebut akan mengakibatkan banyaknya hukum kepemilikan (ownership), dan adanya perubahan kepemilikan setiap kali karya cipta tersebut melewati batas negara. Oleh karenanya, beberapa penulis serta

\footnotetext{
${ }^{19}$ Yu, Peter K, op.cit., hlm.2.

${ }^{20}$ Ibid.
} 
pengadilan menolak penafsiran tersebut.

b. Pendekatan kedua menyebutkan bahwa Prinsip National Treatment sebagai suatu ketentuan non diskriminatif, yang membatasi kemampuan suatu negara untuk membuat suatu ketentuan perundangundangan yang memperlakukan penulis domestik lebih baik daripada penulis asing.

Setelah melakukan pengujian terhadap dua penafsiran tersebut, pengadilan Banding Amerika Serikat, pada putaran ke dua, mengadopsi penafsiran ke-dua, yakni bahwa prinsip National Treatment sebagai suatu ketentuan non diskriminatif. Berdasarkan penafsiran tersebut, pengadilan tidak harus mendasarkan diri pada hukum dimana pelanggaran terjadi, dalam hal ini Amerika Serikat, sebagai hukum yang menentukan kepemilikan (ownership).

Dalam menentukan masalah kepemilikan, hakim pengadilan Banding menggunakan hukum dari negara yang memiliki hubungan paling signifikan dengan karya cipta dan para pihak dalam sengketa, yakni dalam hal ini hukum Rusia. Hubungan paling signifikan antara karya cipta, para pihak dan negara Rusia, meliputi:

a. Karya cipta dalam sengketa adalah hasil karya dari warga negara Rusia.

b. Karya cipta tersebut pertamakali dipublikasikan di Rusia.

c. Rusia merupakan Country of Origin dari karya cipta sebagaimana ketentuan dalam Konvensi Berne.

Hal ini berarti HPI Amerika serikat menunjuk ke arah hukum Rusia sebagai negara yang memiliki hubungan paling signifikan dengan karya cipta dan para pihak dalam sengketa. Jadi hakim pengadilan wilayah New York telah menemukan lex cause dalam menentukan masalah kepemilikan (ownership) yaitu hukum Rusia.

\section{Kualifikasi Tahap Kedua.}

Kualifikasi pada tahap ini harus dijalankan berdasarkan sistem kualifikasi intern yang dikenal pada lex cause. Pada tahap ini semua fakta dalam kasus harus dikualifikasikan kembali berdasarkan kategori lex cause. $^{21}$

Setelah Lex cause ditetapkan, maka pada tahap kedua ini hakim New York akan melakukan kualifikasi ulang menurut hukum intern Rusia. Setelah seluruh fakta dalam perkara dikualifikasikan ulang berdasarkan hukum Rusia, perkara tersebut ternyata juga dikualifikasikan sebagai masalah kepemilikan (ownership). Masalah kepemilikan (ownership) diatur dalam Hukum Hak Cipta Rusia, menurut Pasal 14 Hukum Hak Cipta Rusia, Itar-tass merupakan pemilik dari kepentingan hak cipta dari artikel yang ditulis oleh pekerjanya. Namun demikian, Pasal 14 ayat (4) mengecualikan perusahan-perusahan surat kabar dari doktrin Work For Hire. $^{22}$ Dengan demikian Itar-Tass hanya dapat menuntut pelanggaran hak cipta dari para pekerjanya, sementara untuk perusahaanperusahaan surat-surat kabar yang tergabung dalam Itar-Tass harus mendasarkan diri pada ketentuan hukum lainnya. Perusahaanperusahaan surat kabar mendasarkan diri pada pasal 11 Hukum Hak Cipta

\footnotetext{
${ }^{21}$ Bayu Seto, op.cit., hlm. 63.

${ }^{22}$ Newman, Jon O, op.cit.
} 
Rusia. Pengadilan distrik membenarkan dan mengakui hak eksklusif dari perusahaan surat kabar atas artikel-artikel yang dimuat dalam hariannya. ${ }^{23}$

4. Mencari Titik-Titik Taut Sekunder (menurut Lex Fori) untuk menentukan sistim hukum yang berlaku (lex Cause). ${ }^{24}$

Sebelumnya hakim telah mengkualifikasikan sengketa sebagai perbuatan melawan hukum. Untuk menentukan hukum manakah yang akan digunakan bagi peristiwa perbuatan melawan hukum tersebut terlebih dulu ditentukan titik taut sekundernya. Adapun titik taut sekunder dapat berupa :

kewarganegaraan, tempat letak benda (situs rei), tempat perbuatan hukum yang bersangkutan dilakukan (locus actus), tempat perjanjian dilaksanakan (locus solutionis), Maksud para pihak (pilihan hukum), tempat diadakan perbuatan-perbuatan resmi yang penting (forum). ${ }^{25}$

Dalam sengketa antara ItarTass Russian Agency melawan Russia Kurrier, titik taut sekunder adalah tempat perbuatan hukum yang bersangkutan dilakukan atau dengan kata lain tempat terjadinya perbuatan melawan hukum (onrechmatige daad, unerlaubte Handlung,unlawfull act, tort.). prinsip ini dikenal dengan prinsip Lex Loci Dellicti. Pada sengketa tersebut, tempat terjadinya perbuatan melawan hukum adalah di New York, Amerika Serikat. Dengan demikian yang menjadi lex cause pada sengketa tersebut adalah Hukum Amerika.

${ }^{23}$ Ibid.

${ }^{24}$ Sunaryati Hartono, op.cit., hlm 94.

${ }^{25}$ Ibid, hlm. 91-93.
5. Menyelesaikan perkara dengan menggunakan kaidah-kaidah hukum intern dari Lex Cause yaitu Hak Cipta Amerika Serikat (U.S Copyright), berdasarkan U.S Copyright ITar-Tass Rusia di denda US\$3,934

\section{Simpulan}

1. Peradilan yang berhak menangani perkara ini adalah peradilan Amerika Serikat, hal ini di dasari atas prinsip Forum Rei, dimana pengadilan yang berwenang menyelesaikan sutau sengketa adalah forum di mana tergugat tinggal) dan prinsip Forum Of Convernice (Forum yang paling menguntungkan tergugat)

2. Untuk menentukan hukum yang digunakan untuk menyelesaikan perkara Itar-Tass Russian Agency melawan Russian Kurier Agency hakim menggunakan kualifikasi bertahap, pada tahap pertama hakim Lex Fori mengunakan hukum atas dasar; karya cipta dalam sengketa adalah hasil karya dari warga Negara Rusia, Karya cipta ini pertama kali dipublikasikan di Rusia dan County of Origin-nya adalah Rusia, setelah hakim Lex Fori memutuskan bahwa hukum Rusia yang di gunakan makan hakim melakukan kulifikasi tahap kedua, pada tahap ini hakim melihat bahwa berdasarkan ketentuan perundang-undangan Rusia perkara ini masuk dalam klasifikasi berdasarkan kepemilikan, dan hukum Rusia menunjuk hukum yang belaku bagi kepemilikan adalah hukum pemilit. Berdasarkan kasus ini 
perbuatan melawan hukum dilakukan di New York Amerika Serika maka hukum yang digunakan untuk menelesaikan kasus ini adalah hukum hak cipta Amerika Serikat.

\section{Daftar Pustaka}

Ahmad M. Ramli, Cyber Law dan HAKI, Dalam Sistem Hukum Indonesia, Refika Aditama, Bandung, 2004

Bayu seto, Dasar-Dasar Hukum Perdata Internasional, Citra Aditya Bakti, Bandung, 2001

C..F.G. Sunaryati hartono, PokokPokok Hukum Perdata Internasional, Binacipta, bandung, 1989

Sudargo Gautama, Pengantar Hukum Perdata Internasional, Putra Abardin, Jakarta, 1999 , Hukum Perdata

Internasional Indonesia, Buku Kedelapan, Jilid ketiga (Bagian Dua), Alumni, Bandung, 1998

Berne Convention for the Protection of Literary and Artistic Works.

US Copyright Act 1976

Newman, Jon O, An Introduction to Intellectual Property, www.law.uconn.edu/homes/sw ilf/ip/cases/itar.htm (18/12/2005),

$\mathrm{Yu}$, Peter K, Conflict of Laws Issues in International Copyright cases, http://www.gigalaw.com/articl es/2001/18/12/2005.

http://en.wikipedia.org/wiki/Ita rTass_Russian_News_Agency _v._Russian_Kurier,_Inc.\#Cas e history dilihat pada 13/5/2013 